\title{
Proses berpikir kritis matematis siswa sekolah menengah pertama melalui discovery learning
}

\author{
Purnama Mulia Farib *, M. Ikhsan, Muhammad Subianto \\ Universitas Syiah Kuala, Jalan Teuku Nyak Arief, Darussalam, Banda Aceh, Aceh, 23111, Indonesia. \\ E-mail: purnama@mhs.unsyiah.ac.id \\ * Corresponding Author
}

\begin{tabular}{|c|c|}
\hline ARTICLE INFO & ABSTRACT \\
\hline $\begin{array}{l}\text { Article history } \\
\text { Received: } 29 \text { Sept. } 2018 \text {; } \\
\text { Revised: } 4 \text { March 2019; } \\
\text { Accepted: } 30 \text { August } 2019 \\
\text { Keywords } \\
\text { proses berpikir kritis, } \\
\text { discovery learning, } \\
\text { pembelajaran matematika; } \\
\text { critical thinking process, } \\
\text { discovery learning, } \\
\text { mathematics learning }\end{array}$ & $\begin{array}{l}\text { Penelitian ini bertujuan untuk mendeskripsikan proses berpikir kritis matematis } \\
\text { dan mengidentifikasi tingkat berpikir kritis matematis siswa yang diberikan } \\
\text { pembelajaran discovery pada pembelajaran matematika. Penelitian ini meng- } \\
\text { gunakan metode penelitian kualitatif. Subjek penelitian adalah } 6 \text { orang siswa } \\
\text { yang diambil dari } 37 \text { siswa kelas VII-E MTsN } 3 \text { Aceh Barat yang dipilih } \\
\text { berdasarkan kemampuan awal matematikanya. Instrumen penelitian meliputi } \\
\text { peneliti, tes berpikir kritis, dan pedoman wawancara. Teknik pengumpulan data } \\
\text { yang digunakan terdiri dari tes berpikir kritis dan wawancara. Teknik analisis } \\
\text { data yang digunakan pada penelitian ini yaitu reduksi data, penyajian data, dan } \\
\text { penarikan kesimpulan. Hasil penelitian menunjukkan bahwa dalam aktivitas } \\
\text { penyelesaian masalah siswa lebih banyak melakukan proses specializing dan } \\
\text { generalizing. Siswa telah mampu mengidentifikasi masalah yang disajikan } \\
\text { serta menyusun langkah penyelesaian yang mungkin untuk menyelesaikan } \\
\text { masalah tersebut, namun pada proses conjecturing dan convincing, siswa masih } \\
\text { perlu dilatih untuk menganalogikan masalah serta menyelesaikan masalah } \\
\text { dengan cara yang beragam. Temuan penelitian ini dapat digunakan guru untuk } \\
\text { merancang pembelajaran matematika yang melatihkan kemampuan berpikir } \\
\text { kritis. }\end{array}$ \\
\hline
\end{tabular}

This study aimed to describe the process of mathematical critical thinking of students who were given discovery learning in mathematics learning. This study was classified as qualitative research. The research subjects were 6 students drawn from 37 students of class VII-E MTsN 3 Aceh Barat, Indonesia, and selected based on their initial mathematical abilities. The research instruments included researchers, critical thinking test, and interview guidelines. The data collection was carried out by giving a critical thinking test conducted after discovery learning and interviewing the research subjects after completing the test. The data in this study were analyzed by data reduction, data presentation, and conclusion drawing. The results showed that in solving problems, students were more dominant in the process of specializing and generalizing. Students have been able to identify the problem presented and arrange possible steps for solving the problem, but in the process of conjecturing and convincing, students still need to be trained in analogizing problems and solving problems in a variety of ways. The findings of this study could be used by teachers to design mathematics learning that exercises critical thinking skills.

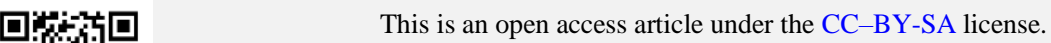

How to Cite: Farib, P., Ikhsan, M., \& Subianto, M. (2019). Proses berpikir kritis matematis siswa sekolah menengah pertama melalui discovery learning. Jurnal Riset Pendidikan Matematika, 6(1), 99-117. doi:https://doi.org/10.21831/jrpm.v6i1.21396 


\section{PENDAHULUAN}

Umumnya pembelajaran matematika bertujuan untuk mengembangkan kemampuan berpikir matematis siswa. Dalam pembelajaran matematika, selain kemampuan berpikir matematis, ada beberapa kompetensi lainnya yang harus dikuasai siswa dalam mempelajari matematika, seperti kemampuan siswa dalam bernalar, memecahkan masalah, berkomunikasi, serta mengaitkan konsep-konsep matematika. National Council of Teachers of Mathematics (NCTM, 2000) menetapkan lima standar kemampuan matematis yang harus dimiliki oleh siswa, antara lain kemampuan komunikasi, kemampuan penalaran, kemampuan koneksi, kemampuan representasi, serta kemampuan pemecahan masalah. Selain itu, Hendriana dan Soemarmo (2017) menyatakan berpikir matematis dapat digolongkan dalam dua jenis, yaitu berpikir tingkat rendah dan berpikir tingkat tinggi. Berpikir tingkat tinggi pada Taksonomi Bloom termasuk pada tahap menganalisis (C4), sintesis (C5), dan evaluasi (C6). Dengan demikian, dapat dipahami bahwa untuk mengembangkan kemampuan berpikir matematis, siswa juga harus mengembangkan kemampuan berpikir tingkat tinggi.

Salah satu kemampuan berpikir tingkat tinggi adalah kemampuan berpikir kritis (Suriawati \& Mundilarto). Maričić dan Špijunović (2015) menyatakan bahwa berpikir kritis dapat diartikan sebagai aktivitas intelektual yang menekankan keterampilan merumuskan, menganalisis, dan mengevaluasi masalah. Hal ini juga didukung oleh Richard dan Elder (2005) yang menyatakan bahwa pemikiran kritis merupakan kegiatan yang berkaitan dengan menganalisis dan mengevaluasi argumen. Selain itu, Ennis (1989) mendefinisikan berpikir kritis sebagai berpikir reflektif untuk mengambil keputusan yang masuk akal terhadap apa yang diyakini atau yang dilakukan. Dari beberapa pendapat para ahli, dapat disimpulkan bahwa kemampuan berpikir kritis merupakan kemampuan berpikir secara efektif yang dapat membantu siswa untuk menganalisis, mengevaluasi, serta mengambil keputusan tentang apa yang akan dilakukan.

Berpikir kritis menjadi penting bagi siswa karena dengan kemampuan ini siswa dapat mengembangkan sikap rasional dan mampu memilih alternatif pilihan yang terbaik bagi dirinya sendiri. Maulana (2017) menyatakan salah satu alasan mengenai perlunya mengembangkan kemampuan berpikir kritis yaitu tuntutan zaman yang menghendaki setiap individu untuk mencari, memilih, dan menggunakan informasi untuk kehidupannya. Jumaisyaroh, Napitupulu, dan Hasratuddin (2015) juga menyatakan perlunya menanamkan kebiasaan berpikir kritis matematis bagi pelajar agar mereka dapat bersikap rasional untuk mencermati berbagai persoalan yang dihadapi dalam kehidupan sehari-hari. Hal ini sejalan dengan amanat Kurikulum 2013, khususnya pembelajaran matematika yang mengharuskan siswa untuk memiliki keterampilan berpikir kritis matematis, agar siswa terlatih untuk menemukan atau membangun pengetahuannya sendiri sebagai penunjang keberhasilan tujuan belajar siswa.

Berpikir kritis matematika berkaitan dengan cara berpikir siswa untuk membangun pengetahuan matematika. Hal yang diperlukan untuk membangun pengetahuan matematika adalah kemampuan awal matematika. Razak (2017) menyatakan kemampuan awal matematika siswa merupakan prasyarat yang harus dimiliki siswa agar proses pembelajaran dapat berjalan dengan baik. Kemampuan awal matematika menggambarkan kesiapan siswa dalam menerima pelajaran yang disampaikan guru. Perbedaan kemampuan awal siswa akan mempengaruhi tingkat penguasaan materi bahan pelajaran pada masing-masing siswa. Kemampuan awal matematika yang baik akan menuntun siswa untuk lebih mudah memahami permasalahan matematika yang melibatkan kemampuan berpikir tingkat tinggi. Hal ini sejalan dengan pendapat Ruseffendi (2006) yang menyatakan bahwa dalam mempelajari topik-topik pembelajaran matematika tidak dapat dilakukan sembarangan, harus ada prasyaratnya. Selanjutnya Winkel (1991) juga berpendapat bahwa kemampuan awal merupakan jembatan untuk menuju kemampuan akhir. Setiap proses pembelajaran memiliki titik tumpu dan berpangkal pada kemampuan awal siswa tertentu untuk dikembangkan menjadi kemampuan yang baru. Dengan demikian dapat disimpulkan bahwa siswa yang memiliki kemampuan awal yang baik berpotensi untuk memiliki keterampilan berpikir tingkat tinggi, sehingga dalam hal ini, keterampilan berpikir kritis dapat diidentifikasi secara lebih mendalam dengan mengelompokkan siswa kedalam beberapa kemampuan awal siswa.

Berpikir matematis dapat dinilai dengan cara menelusuri proses berpikir matematis siswa. Proses berpikir matematis berkaitan dengan tingkah laku atau aktivitas siswa dalam menyelesaikan masalah matematis. Widodo (2012) menyatakan kemampuan berpikir matematis dapat dilihat melalui proses berpikir yang dikontruksikan dari pengamatan tingkah laku. Hal ini sejalan dengan pendapat Subanji 
(2006) yang mengungkapkan bahwa proses berpikir berkaitan erat dengan aktivitas mental yang digunakan untuk memahami, merumuskan, dan menyelesaikan masalah serta membuat keputusan. Selain itu, Faridah (2013) menyatakan bahwa guru perlu mengetahui proses berpikir siswa dalam menyelesaikan masalah matematika, sehingga guru mampu melacak letak kesalahan dan jenis kesalahan yang dilakukan siswa dalam penyelesaian masalah matematika. Selanjutnya Wulandari (2014) menyatakan bahwa mengetahui proses berpikir siswa dalam pembelajaran dapat dijadikan pertimbangan bagi guru untuk merancang pembelajaran yang sesuai dengan proses berpikir siswa, sehingga dapat berpengaruh pada pengembangan potensi yang ada dalam diri siswa. Oleh karena itu, proses berpikir siswa dalam menyelesaikan masalah menjadi suatu hal yang penting untuk diketahui, karena proses pembelajaran yang dialami setiap orang berbeda dengan yang lain.

Proses berpikir dapat dilihat dari penyelesaian masalah yang dilakukan siswa. Mason, Burton, dan Stacey (2010) menyatakan bahwa proses berpikir didasarkan pada specializing (mengkhususkan), generalizing (menggeneralisasi), conjecturing (menduga), dan convincing (meyakinkan). Hal ini sejalan dengan pendapat yang dikemukakan Polya (1973) yang menyatakan bahwa dalam penyelesaian masalah terdapat aktivitas specializing dan generalizing. Hal ini juga didukung oleh Lin (2006) yang menyatakan bahwa teori berpikir Mason et al (2010) didasarkan pada pemikiran Polya (1973). Berdasarkan pendapat para ahli, dapat disimpulkan bahwa proses berpikir siswa dapat digali dengan cara mengkaji lebih rinci beberapa komponen berpikir, yaitu specializing (mengkhususkan), generalizing (menggeneralisasi), conjecturing (menduga), dan convincing (meyakinkan). Oleh karena itu, dalam proses pembelajaran penting untuk mengetahui proses berpikir siswa yang bertujuan untuk menilai atau melihat kemampuan berpikir matematis siswa.

Kenyataan di lapangan menunjukkan bahwa kemampuan berpikir matematis siswa saat ini masih kurang optimal. Berdasarkan hasil studi PISA, hampir setengah siswa di Indonesia $(43,5 \%)$ tidak mampu menyelesaikan soal PISA yang paling sederhana, sepertiga siswa $(33,1 \%)$ hanya bisa mengerjakan soal jika pertanyaan dari soal kontekstual dan diberikan secara eksplisit serta data yang dibutuhkan untuk mengerjakan soal diberikan secara tepat, dan hanya $0,1 \%$ siswa Indonesia yang mampu mengembangkan dan mengerjakan pemodelan matematika yang menuntut keterampilan berpikir dan penalaran (Wijaya, 2012). Hal ini didukung oleh hasil penelitian Irawan, Rahardjo, dan Sarwanto (2017) yang menyatakan bahwa hasil rata-rata siswa dari semua aspek kemampuan berpikir kritis masih dibawah 50\% yaitu hanya 44,87\%. Selanjutnya hasil penelitian Danaryanti dan Lestari (2018) juga menunjukkan bahwa kemampuan berpikir kritis siswa termasuk dalam kategori sedang. Pada aspek interpretasi $44,77 \%$ siswa dapat menjawab dengan benar, aspek analisis sebanyak 43,55\%, aspek evaluasi $47,93 \%$, aspek kesimpulan 40,65\%, aspek penjelasan $29,03 \%$, dan aspek pengaturan diri $61,30 \%$. Hasil penelitian tersebut juga menunjukkan bahwa pada indikator penarikan kesimpulan kemampuan berpikir siswa berada pada kategori sedang, pada indikator asumsi berada pada kategori sangat tinggi, pada indikator deduksi berada pada kategori tinggi, pada indikator menafsirkan informasi berada pada kategori sedang, dan pada indikator menganalisis argumen berada kategori rendah. Hasilhasil penelitian tersebut jelas mengindikasikan bahwa kemampuan berpikir kritis matematis siswa masih belum dikembangkan secara optimal di sekolah, sehingga masih banyak siswa yang kesulitan dalam menyelesaikan soal-soal pemecahan masalah yang menuntut siswa untuk memiliki keterampilan berpikir tingkat tinggi.

Selain itu, hasil studi pendahuluan yang dilakukan di MTsN 3 Aceh Barat juga menunjukkan kemampuan berpikir matematis siswa masih belum berkembang dengan baik. Hal ini terlihat dari jawaban siswa yang menunjukkan bahwa siswa hanya menyelesaikan masalah yang diberikan pada soal dengan tepat, tanpa mencoba untuk memahami esensi dari masalah yang diberikan. Gambar 1 menyajikan soal yang menuntut siswa untuk berpikir kritis matematis yang diberikan kepada siswa di MTsN 3 Aceh Barat.

Dua puluh lima siswa kelas VII MTSN 3 Aceh Barat mengunjungi pameran buku. Di tempat itu sedang ada obral besar-besaran untuk 65 jenis buku cerita, yang terdiri dari 23 buku cerita orang dewasa dan siswanya merupakan buku cerita anak-anak. Pada siswa tertarik untuk membeli buku-buku cerita anakanak tersebut. Untuk membeli 8 buku cerita anak-anak, maka para siswa harus membayar Rp60.000,00. Namun jika MTSN3 Aceh Barat akan memborong seluruh buku cerita anak-anak tersebut, maka sekolah cukup membayar Rp210.000,00. Menurut Kamu, cara pembelian mana yang lebih menguntungkan? Jelaskan alasannya.

Gambar 1. Contoh Soal Tes Berpikir Kritis 
Soal tersebut adalah soal berpikir kritis matematis untuk SMP yang dimodifikasi dari Rohaeti (2010). Soal tersebut melibatkan indikator berpikir kritis yaitu memutuskan suatu tindakan serta meminta siswa untuk menyertakan alasan dalam mengambil suatu keputusan. Adapun contoh jawaban siswa dalam menyelesaikan soal tersebut disajikan pada Gambar 2.

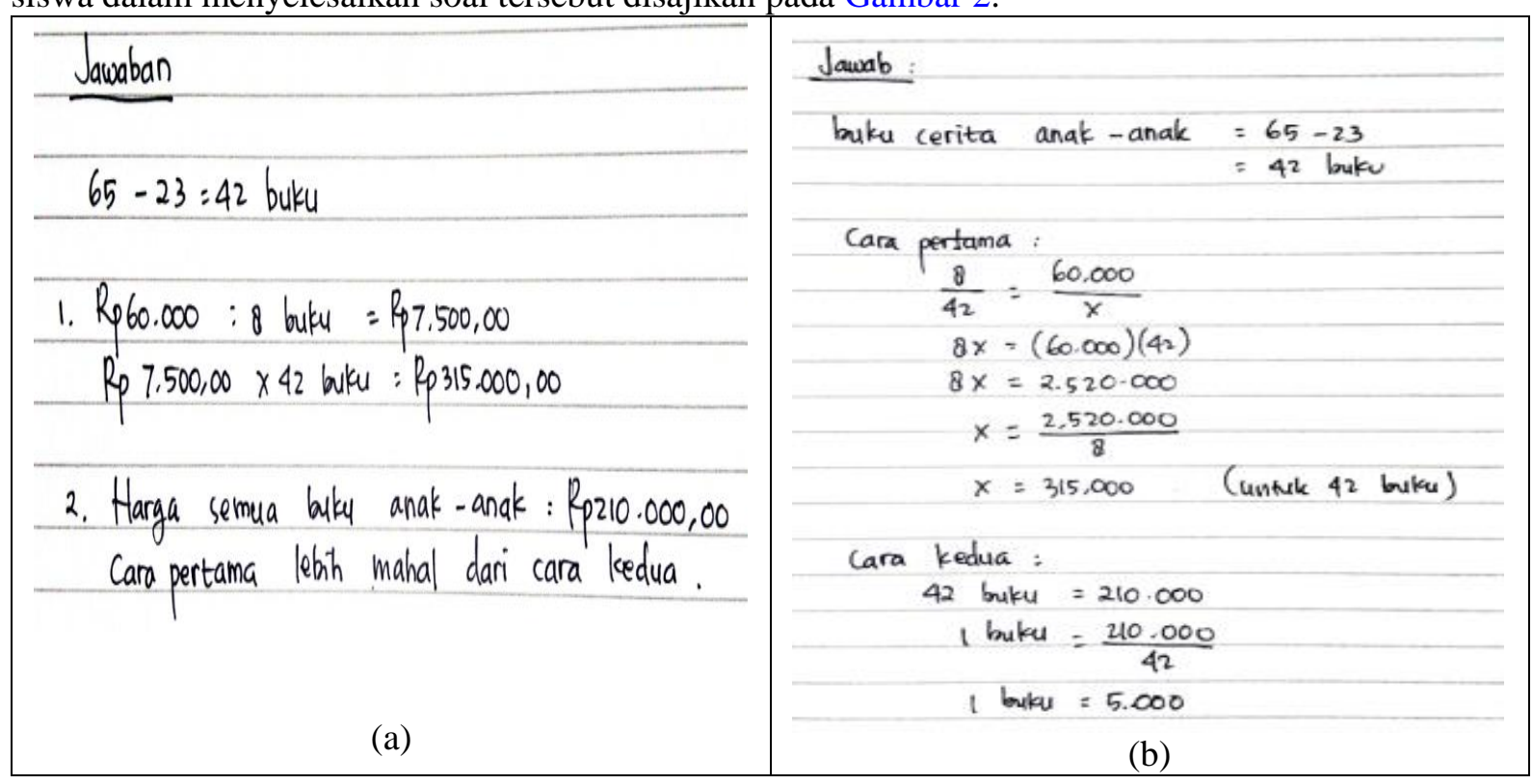

Gambar 2. Contoh Jawaban Siswa dalam Mengerjakan Soal Berpikir Kritis

Gambar 2 menunjukkan jawaban siswa dari hasil studi pendahuluan untuk melihat proses berpikir kritis siswa. Pada Gambar 2 (a) terlihat bahwa siswa menyelesaikan masalah dengan benar, namun siswa tidak menuliskan langkah-langkah yang dilakukan dalam penyelesaian masalah. Siswa juga tidak mengkhususkan masalah terlebih dahulu dan tidak menuliskan kesimpulan dari penyelesaian masalah. Pada Gambar 2 (b) terlihat bahwa siswa menuliskan langkah-langkah penyelesaian masalah dan menyelesaikannya dengan tepat dan benar, namun siswa tidak menuliskan keputusan yang harus diambil dalam penyelesaian masalah. Siswa juga tidak menuliskan informasi yang diketahui dan ditanyakan dari soal. Dengan demikian dapat disimpulkan bahwa siswa mampu menyelesaikan masalah matematika yang diberikan, namun hasil penyelesaian siswa belum menggambarkan kemampuan berpikir tingkat tinggi yang dimiliki siswa secara lebih rinci sehingga perlu digali proses berpikir siswa dalam menyelesaikan masalah matematika.

Kurikulum 2013 menyarankan agar pembelajaran di kelas harus menempatkan siswa sebagai subjek untuk membangun pengetahuannya sendiri. Hosnan (2014) menyatakan dalam Kurikulum 2013 disarankan pembelajaran yang mengintegrasikan penerapan pendekatan saintifik. Ada tiga model pembelajaran yang memuat pendekatan saintifik dalam proses pembelajaran, salah satunya model discovery learning. Sani (2015) juga mengungkapkan bahwa ada beberapa model pembelajaran yang dapat diterapkan dalam proses pembelajaran yang bisa mengintegrasikan pola pengalaman belajar ilmiah, termasuk pembelajaran penemuan (discovery learning). Sumardyono, Priatna, dan Anggraena (2016) menyatakan bahwa discovery learning memiliki karakteristik pada penemuan konsep atau prinsip yang dilakukan sendiri oleh siswa dengan cara mengidentifikasi dan mengorganisir informasi yang diberikan sehingga dapat membentuk pengetahuan dan mengembangkan intuisi siswa. Berdasarkan pendapat ahli, dapat disimpulkan bahwa model pembelajaran discovery learning termasuk salah satu model pembelajaran yang dapat diterapkan di kelas untuk mencapai tujuan pembelajaran matematika.

Mengingat pentingnya berpikir kritis dalam proses pembelajaran matematika, dan proses berpikir tersebut secara teoritis dapat difasilitasi melalui model discovery learning, maka perlu dikaji lebih mendalam lagi mengenai proses berpikir kritis siswa melalui penerapan model discovery learning dalam pembelajaran matematika. Meskipun telah banyak penelitian-penelitian yang dilakukan mengenai proses berpikir, diantaranya penelitian yang dilakukan oleh Setyaningsih dan Agoestanto (2014) yang mengidentifikasi tahap berpikir kritis dalam tugas pengajuan masalah, Wardhani, Subanji, dan Dwiyana (2016) yang melakukan penelitian untuk mendeskripsikan proses berpikir siswa berkemampuan tinggi 
dan rendah dalam menyelesaikan masalah matematika, serta penelitian yang dilakukan oleh Amir (2015) yang bertujuan untuk mengidentifikasi proses berpikir kritis siswa dalam memecahkan masalah berbentuk soal cerita berdasarkan perbedaan gaya belajar siswa. Namun penelitian-penelitian yang telah dilakukan tersebut belum menggambarkan secara spesifik bagaimana proses pembelajaran atau model pembelajaran apa yang digunakan. Berdasarkan hal tersebut, maka penelitian ini bertujuan untuk mendeskripsikan proses berpikir kritis matematis siswa yang dikaitkan dengan indikator berpikir kritis melalui penerapan model discovery learning pada pembelajaran matematika.

\section{METODE}

Penelitian ini merupakan penelitian kualitatif. Penelitian ini menghasilkan data deskriptif berupa kata-kata tertulis atau lisan dari orang-orang dan perilaku yang diamati. Subjek pada penelitian ini adalah 6 orang siswa yang diambil dari 37 siswa kelas VII-E MTsN 3 Aceh Barat, Indonesia, yang diberikan tes berpikir kritis setelah discovery learning dilaksanakan. Subjek dipilih berdasarkan kemampuan awal matematika siswa dan kriteria pemilihan subjek yang telah ditentukan peneliti. Alasan peneliti memilih subjek yang didasarkan pada kemampuan awal siswa karena perbedaan kemampuan awal siswa akan mempengaruhi tingkat penguasaan materi bahan pembelajaran. Selain itu, kemampuan awal siswa juga sangat menentukan dalam proses berpikir siswa dalam memahami masalah yang diberikan (Razak, 2017). Pemilihan subjek penelitian didasarkan beberapa kriteria, yaitu (1) telah mendapatkan discovery learning, (2) berdasarkan informasi dari guru matematika, siswa yang dapat mengkomunikasikan idenya dengan jelas, baik secara tertulis maupun lisan, dan (3) mampu menjawab indikator berpikir kritis baik secara tertulis maupun lisan. Prosedur pemilihan subjek dalam penelitian ini, antara lain: (1) pemberian tes kemampuan awal, (2) pemberian tes berpikir kritis pada semua siswa, (3) menganalisis hasil tes berpikir kritis, dan (3) memilih subjek untuk diwawancara yang didasarkan pada kriteria yang telah ditentukan, dan selanjutnya diwawancarai untuk mendapatkan data proses berpikir kritis matematis. Proses yang diidentifikasi dalam penelitian adalah hasil kerja siswa setelah menyelesaikan tes berpikir kritis matematis (TBKM) dan wawancara yang dilakukan setelah TBKM. Pada penelitian ini, peneliti bertindak sebagai instrumen utama karena peneliti yang merencanakan, merancang, melaksanakan, mengumpulkan data, menganalisis data, menarik kesimpulan, dan menyusun laporan penelitian. Selain itu, instrumen penunjang dalam penelitian ini adalah instrumen tes kemampuan berpikir kritis pada materi garis dan sudut serta pedoman wawancara. Soal TBKM telah divalidasi oleh dua orang dosen ahli yang berasal Prodi Pendidikan Matematika UIN Ar-Raniry Banda Aceh, dan hasilnya berada pada kategori "baik". Soal tes berpikir kritis yang digunakan dalam penelitian ini seperti yang disajikan pada Tabel 1 .

Pedoman wawancara dibuat oleh peneliti sebagai alat bantu dalam pengambilan data di lapangan. Pedoman wawancara ini bersifat semi terstruktur dengan tujuan agar subjek dapat mengemukakan pendapat dan ide-idenya mengenai penyelesaian masalah yang telah dibuat. Dalam penelitian ini data yang diperoleh berupa catatan hasil pekerjaan siswa dalam menyelesaikan masalah secara tertulis dan hasil wawancara siswa setelah mengerjakan masalah matematika. Adapun indikator proses berpikir yang digunakan dalam penelitian ini ditinjau dari proses berpikir matematis yang dikemukakan oleh Mason et al. (2010), yaitu specializing, generalizing, conjecturing, dan convincing seperti pada Tabel 2.

Data penelitian dianalisis berdasarkan analisis data yang dikemukakan oleh Miles dan Huberman (1992), yaitu reduksi data, penyajian data, dan penarikan kesimpulan. Kegiatan reduksi data yang dilakukan yaitu menganalisis hasil jawaban siswa dalam menyelesaikan soal tes berpikir kritis, menganalisis hasil wawancara subjek terhadap penyelesaian tes berpikir kritis, membandingkan hasil tes berpikir kritis dan wawancara terhadap subjek dengan sumber lain, dan menyusun hasil transkipsi sehingga memudahkan peneliti pada saat analisis data. Pada tahap penyajian data, data yang disajikan berupa data hasil tes berpikir kritis dan data hasil wawancara terhadap subjek. Data dikategorisasikan berdasarkan kemampuan awal matematika dan disajikan dalam bentuk teks yang bersifat naratif. Klasifikasi data disajikan berdasarkan kriteria subjek. Pada tahap penarikan kesimpulan, peneliti mendeskripsikan proses berpikir yang dilakukan siswa dalam menyelesaikan masalah berpikir kritis dengan mengkaji proses berpikir yang dikemukakan Mason et al (2010). 
Jurnal Riset Pendidikan Matematika, 6 (1), 2019 - 104

Purnama Mulia Farib, M. Ikhsan, Muhammad Subianto

Tabel 1. Indikator dan Soal Tes Berpikir Kritis

\begin{tabular}{|c|c|c|}
\hline No. Soal & Indikator Berpikir Kritis & Soal Tes Berpikir Kritis \\
\hline 1. & $\begin{array}{l}\text { Memeriksa kebenaran } \\
\text { argumen, pernyataan, } \\
\text { dan proses solusi. }\end{array}$ & $\begin{array}{l}\text { Perhatikan pernyataan berikut: } \\
\text { Pernyataan 1: Ukuran suatu sudut lancip sama dengan selisih } \\
\text { pelurusnya dengan dua kali penyikunya. } \\
x^{\circ}=(180-x)^{\circ}-2(90-x)^{\circ} \\
\text { Pernyataan 2: Penyiku suatu sudut sama dengan jumlah dari ukuran } \\
\text { suatu sudut lancip dan setengah kali pelurusnya. } \\
\left(90-x^{\circ}\right)=x^{\circ}+\frac{1}{2}(180-x)^{\circ} \\
\text { Analisislah tiap pernyataan tersebut! Kemudian tetapkan argumen } \\
\text { yang mana terjadi kesalahan konsep/prosedur penyelesaian. Sertakan } \\
\text { alasanmu yang mendasari argumen yang benar. }\end{array}$ \\
\hline 2. & Menfokuskan pertanyaan & $\begin{array}{l}\text { Jarum panjang sebuah jam bergerak dari pukul } 10.15 \text { sampai pukul } \\
\text { 12.45. Bagaimana menentukan banyak sudut siku-siku dan sudut lurus } \\
\text { yang dijalani oleh jarum jam tersebut? }\end{array}$ \\
\hline \multirow[t]{2}{*}{3.} & $\begin{array}{l}\text { Mengidentifikasi asumsi } \\
\text { yang mendasari penyele- } \\
\text { saian masalah. }\end{array}$ & Perhatikan gambar berikut! \\
\hline & & $\begin{array}{l}\text { Jika diberikan } m \angle B C O=60^{\circ}, m \angle B E C=30^{\circ}, m \angle B C Q=80^{\circ} \text {, } \\
\text { benarkah asumsi bahwa besar sudut } F O E=70^{\circ} \text { dan } m \angle D F O= \\
m \angle B C E \text { ? Berikan alasan yang mendukung jawabanmu! }\end{array}$ \\
\hline \multirow[t]{2}{*}{4.} & $\begin{array}{l}\text { Mengidentifikasi data } \\
\text { relevan dan tidak relevan } \\
\text { suatu masalah matema- } \\
\text { tika. }\end{array}$ & $\begin{array}{l}\text { Farhan salah satu pekerja pada } \\
\text { pembangunan jalur kereta api. } \\
\text { Farhan mendapat tugas untuk } \\
\text { merancang jalur kereta api } \\
\text { seperti yang ditunjukkan pada } \\
\text { gambar. Farhan merancang } \\
\text { salah satu sudut yang dibentuk } \\
\text { oleh perpotongan dua jalur } \\
\text { kereta api tersebut dengan } \\
\text { sudut } 60^{\circ} \text { agar jalur kereta api } \\
\text { menjadi efisien } \text { bagi } \\
\text { penumpang. } \\
\text { a. Jika besar sudut A adalah } \\
60^{\circ} \text {, bagaimana menentukan besar sudut yang lainnya yang } \\
\text { terbentuk pada jalur kereta api tersebut? Tuliskan alasan yang } \\
\text { mendukung jawabanmu! (gunakan sifat-sifat sudut pada dua garis } \\
\text { sejajar) }\end{array}$ \\
\hline & $\begin{array}{l}\text { Menyusun jawaban/ } \\
\text { menyelesaikan masalah } \\
\text { matematika disertai } \\
\text { alasan. }\end{array}$ & $\begin{array}{l}\text { b. Jalur kereta api tersebut menjadi kurang efektif jika besar sudut E } \\
\text { dan G sama besar. Benarkah kesimpulan tersebut? Mengapa? }\end{array}$ \\
\hline
\end{tabular}

Tabel 2. Indikator Proses Berpikir Kritis Siswa

\begin{tabular}{ll}
\hline \multicolumn{1}{c}{ Proses Berpikir Matematis } & \multicolumn{1}{c}{ Indikator } \\
\hline Specializing (mengkhususkan) & Mengidentifikasi masalah. \\
& Menyusun dan mencoba berbagai strategi yang mungkin. \\
Generalizing (menggeneralisasi) & Merefleksikan ide / gagasan yang dibuat. \\
& Memperluas cakupan hasil yang diperoleh. \\
Conjecturing (menduga) & Menganalogikan pada kasus yang sejenis. \\
Convincing (meyakinkan) & Mencari alasan mengapa hasil yang diperoleh bisa muncul. \\
& Membentuk suatu pola dari hasil yang diperoleh. \\
& Membuat kebalikan dari pola yang telah terbentuk. \\
\hline
\end{tabular}




\section{HASIL DAN PEMBAHASAN}

Pada penelitian ini, data hasil penelitian diperoleh dari 6 siswa yang menjadi subjek utama penelitian. Keenam siswa tersebut mewakili siswa dengan kemampuan awal tinggi, sedang, dan rendah. Jawaban keenam siswa dalam menyelesaikan TBKM dan hasil wawancara dideskripsikan untuk menggambarkan proses berpikir kritis matematis untuk masing-masing level kemampuan. Adapun deskripsi tersebut diuraikan sebagai berikut.

\section{Proses Berpikir Kritis Siswa Berkemampuan Tinggi}

Berikut disajikan proses berpikir kritis matematis untuk siswa dengan kemampuan tinggi (siswa AST) dalam menyelesaikan masalah berpikir kritis.

\section{Proses Berpikir Subjek AST dalam Menyelesaikan TBKM 1}

Gambar 3 menyajikan hasil pekerjaan subjek AST dalam menyelesaikan masalah 1. Dari hasil pekerjaan siswa tersebut dapat dilihat bahwa AST tidak menuliskan konsep yang termuat dalam argumen/pernyataan. AST menguraikan proses perhitungan matematika dengan benar, namun hanya menuliskan satu letak kesalahan argumen dan tidak menuliskan alasan dari setiap langkah penyelesaian masalah.

1.a. $x^{\circ}=(180-x)^{\circ}-2(90-x)^{\circ}$
$=180-x-180+2 x$
$x^{\circ}=x^{\circ}$
jadi, pernyataan yang pertama benar.
$\quad(90-x)^{\circ}=x+\frac{1}{2}(180-x)^{\circ}$
b. $(90-x)^{\circ}=x+90-\frac{1}{2} x$
$(90-x)^{\circ}=\left(90+\frac{1}{2} x\right)^{\circ}$
Jadi, pernyataan yang kedua salah, bukan $(90-x)^{\circ}$
tetapi $\left(90+\frac{1}{2} x\right)^{\circ}$

Gambar 3. Hasil Kerja AST dalam Menyelesaikan Masalah 1

Berdasarkan hasil wawancara, diperoleh informasi bahwa dalam menyelesaikan masalah 1, subjek AST menjelaskan dengan baik informasi yang diberikan pada soal, meskipun AST tidak menuliskan informasi tersebut pada lembar jawaban. AST juga menentukan langkah penyelesaian dan menerapkan prosedur penyelesaian masalah dengan baik. Namun, AST tidak menjelaskan alasan penyelesaian masalah yang digunakan berdasarkan konsep-konsep matematika. Hal ini terlihat pada petikan wawancara berikut.

Peneliti : Untuk soal nomor 1, apa yang kamu pikirkan mengenai soal tersebut?

AST : Menurut saya, pada soal tersebut diberikan dua buah pernyataan, kemudian kita diminta untuk menentukan nilai kebenaran dari pernyataan tersebut, bu.

Peneliti : Selanjutnya, langkah apa yang kamu gunakan utnuk menentukan kebenaran argumen yang diminta?

AST : Dari pernyataan tersebut, kita dapat memisalkan ukuran sudut lancip, ukuran sudut pelurus, dan ukuran sudut penyiku.

Peneliti : Terus?

AST : (mencoba berpikir)

Dari soal yang diberikan, kita misalkan sudut lancip $=x^{\circ}$,

Sudut pelurus $=(180-x)^{\circ}$, dan sudut penyiku $=(90-x)^{\circ}$.

Peneliti : Selanjutnya, bagaimana cara kamu menentukan benar atau salah pernyataan tersebut?

AST : Diselesaikan satu per satu dengan menggunakan cara aljabar. Untuk pernyataan 1 kita dapat nilai $x^{\circ}=x^{\circ}$. Berarti pernyataan 1 benar.

Peneliti : Terus? 
AST : Karena hasil yang diperoleh juga sama dengan yang dicari, berarti pernyataan itu benar, bu.

Peneliti : Dari kedua pernyataan tersebut, apakah ada kesalahan dalam pernyataan yang diajukan pada soal?

AST : Ada bu, pada pernyataan kedua.

Peneliti : Dimana letak kesalahan pada pernyataan tersebut?

AST : Jawaban dari pernyataan 2. Karena pada jawabannya hasilnya tidak sama.

Peneliti : Apa yang dapat kamu simpulkan dari argumen tersebut?

AST : Yang pertama benar, yang kedua salah.

Peneliti : Baik, apa alasan kamu menyatakan argumen tersebut benar atau salah?

AST : Karena hasil yang diperoleh tadi tidak sama bu (sambil menunjukkan jawaban yang telah diperoleh)

Peneliti : Apakah ada alasan lain dari jawaban yang kamu miliki?

AST : Tidak ada bu.

Berdasarkan hasil tes dan wawancara, dapat disimpulkan bahwa dalam menyelesaikan TBKM 1, subjek AST belum menerapkan proses penyelesaian masalah yang dikemukakan oleh Mason et al (2010) secara menyeluruh. Pada proses specializing, AST mengidentifikasi konsep yang termuat dalam argumen serta menyusun strategi yang digunakan untuk penyelesaian masalah dengan baik, namun AST tidak menuliskan hasil identifikasi konsep pada lembar jawaban. Pada proses generalizing, AST menerapkan langkah-langkah penyelesaian dengan menggunakan prosedur perhitungan matematika yang tepat dan benar. AST juga mampu menjelaskan langkah penyelesaian yang dilakukan dengan baik. Pada proses conjecturing, AST menetapkan nilai kebenaran dari argumen yang diberikan, namun AST kesulitan dalam menjelaskan makna dari nilai kebenaran yang ditentukan. Pada proses convincing, alasan yang digunakan AST dalam pengambilan kesimpulan dari penyelesaian masalah tidak didasarkan pada konsep matematika, sehingga AST kesulitan dalam menjelaskan/meyakinkan kesimpulan yang diperoleh dalam penyelesaian masalah.

Proses Berpikir Subjek AST dalam Menyelesaikan TBKM 2

Gambar 4 menunjukkan hasil pekerjaan subjek AST dalam menyelesaikan masalah 2. Hasil kerja subjek AST dalam menyelesaikan masalah 2 menunjukkan bahwa AST telah mampu menuliskan data yang diketahui dan masalah yang ditanyakan dengan benar, serta menuliskan informasi yang ditanyakan dengan tepat. AST juga menuliskan jawaban yang relevan dengan permasalahan dengan menggunakan prosedur perhitungan yang benar.

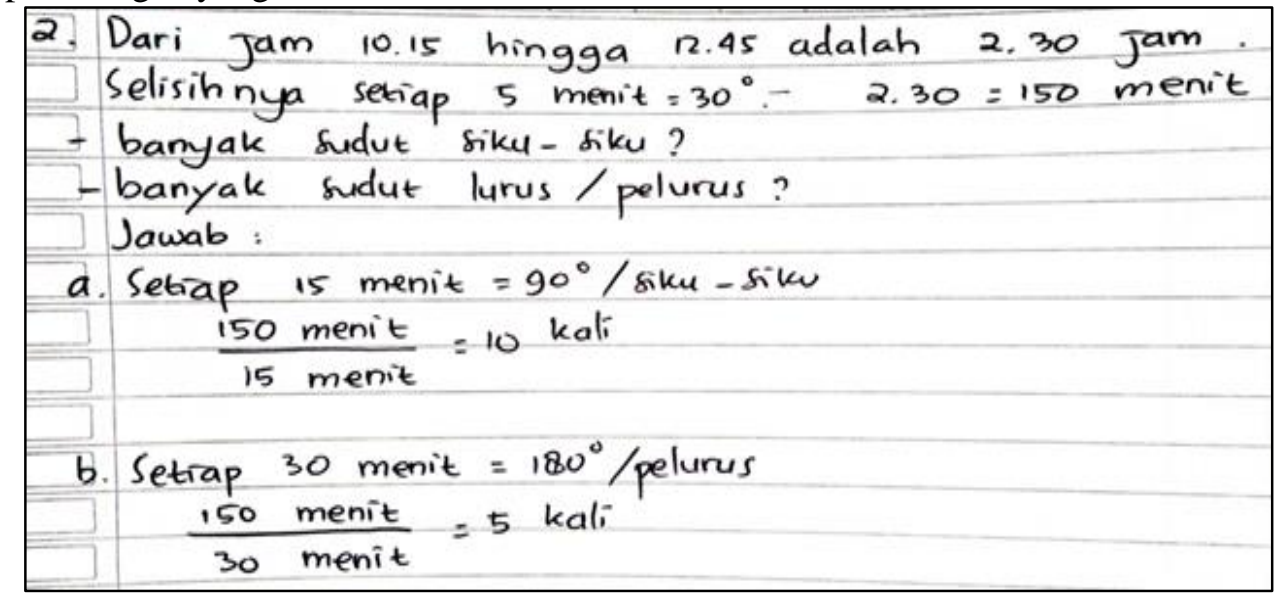

Gambar 4. Hasil Kerja Subjek AST dalam Menyelesaikan Masalah 2

Berdasarkan hasil wawancara, diperoleh informasi bahwa dalam menyelesaikan masalah 2, AST menyusun masalah menjadi bagian-bagian yang lebih khusus untuk memperoleh banyak sudut siku-siku dan sudut lurus yang dibentuk oleh jarum jam. Selain itu, AST juga menjelaskan jawaban yang diperoleh dari penyelesaian masalah dengan menggunakan konsep-konsep matematika. Berdasarkan hasil tes dan wawancara, dapat disimpulkan bahwa dalam menyelesaikan masalah TBKM 2, subjek telah melakukan ke empat proses penyelesaian masalah yang dikemukakan oleh Mason et al (2010), namun masih 
kesulitan pada proses conjecturing. Pada proses specializing, AST mampu mengidentifikasi informasi yang diketahui dan ditanyakan dari soal menjadi lebih khusus. Pada proses generalizing, AST mampu menjelaskan dan menerapkan langkah-langkah penyelesaian yang harus dilakukan dengan baik. Pada proses conjecturing, AST tidak mencoba penyelesaian masalah pada contoh-contoh yang sejenis. Pada proses convincing, AST telah mampu menjelaskan alasan dari langkah penyelesaian yang dilakukan dengan baik dan benar.

Proses Berpikir Subjek AST dalam Menyelesaikan TBKM 3

Gambar 5 menyajikan hasil kerja subjek AST dalam menyelesaikan masalah 3. Hasil kerja subjek AST dalam menyelesaikan masalah 3 menunjukkan bahwa subjek tidak mengidentifikasi syarat yang diperlukan dalam pemecahan masalah, subjek hanya menuliskan 2 langkah penyelesaian masalah, dan mengidentifikasi penyelesaian masalah berdasarkan gambar, bukan melalui proses perhitungan matematika.

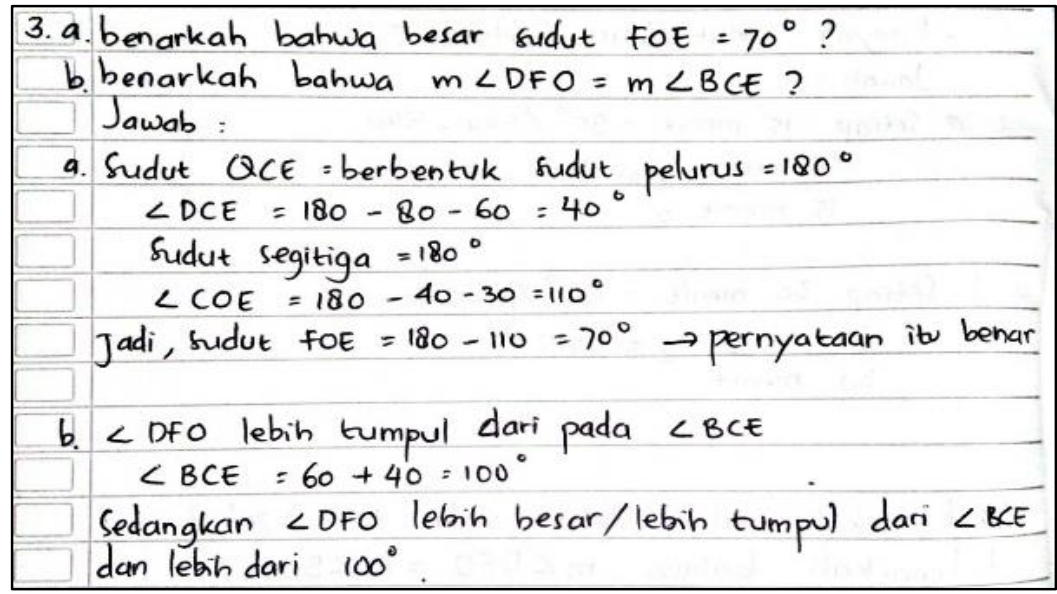

Gambar 5. Hasil Kerja Subjek AST dalam Menyelesaikan Masalah 3

Berdasarkan hasil wawancara, diperoleh informasi bahwa dalam menyelesaikan masalah 3, subjek AST memahami masalah yang ditanyakan, namun subjek tidak mengidentifikasi syarat yang diperlukan untuk menyelesaikan masalah, hanya menggunakan 2 langkah penyelesaian untuk memeriksa kebenaran asumsi dan tidak menggunakan sifat-sifat sudut yang telah dipelajari, subjek tidak menggunakan proses perhitungan matematika dan hanya menggunakan gambar untuk mengidentifikasi kebenaran asumsi, serta tidak menuliskan kesimpulan secara kesuluruhan dari asumsi yang diberikan.

Berdasarkan hasil tes dan wawancara, dapat disimpulkan bahwa proses berpikir yang dilakukan AST dalam menyelesaikan masalah 3 yaitu meliputi proses specializing, generalizing, dan conjecturing. Pada proses specializing, AST berhasil mengidentifikasi informasi yang diketahui dan ditanyakan dari soal, namun AST tidak mengidentifikasi syarat yang diperlukan untuk penyelesaian masalah. Pada proses generalizing, AST mampu menjelaskan langkah-langkah yang digunakan untuk penyelesaian masalah dengan baik, namun AST kesulitan menjelaskan alasan yang digunakan untuk menentukan langkah penyelesaian. Pada proses conjecturing, AST menduga jawaban dari penyelesaian masalah hanya berdasarkan gambar yang disajikan. AST kesulitan menjelaskan alasan dari penyelesaian masalah.

\section{Proses Berpikir Subjek AST dalam Menyelesaikan TBKM 4}

Gambar 6 menyajikan hasil kerja subjek AST dalam menyelesaikan masalah 4. Hasil kerja subjek AST dalam menyelesaikan masalah 4 menunjukkan bahwa subjek belum mengidentifikasi konsep yang termuat dalam soal, tidak menyusun konsep matematika dalam bentuk model matematika, tidak menggunakan proses perhitungan matematika dalam menyelesaikan masalah, dan hanya memanfaatkan gambar untuk penyelesaian masalah. Subjek menuliskan alasan dari penyelesaian masalah, namun masih kurang tepat. 
Jurnal Riset Pendidikan Matematika, 6 (1), 2019 - 108

Purnama Mulia Farib, M. Ikhsan, Muhammad Subianto

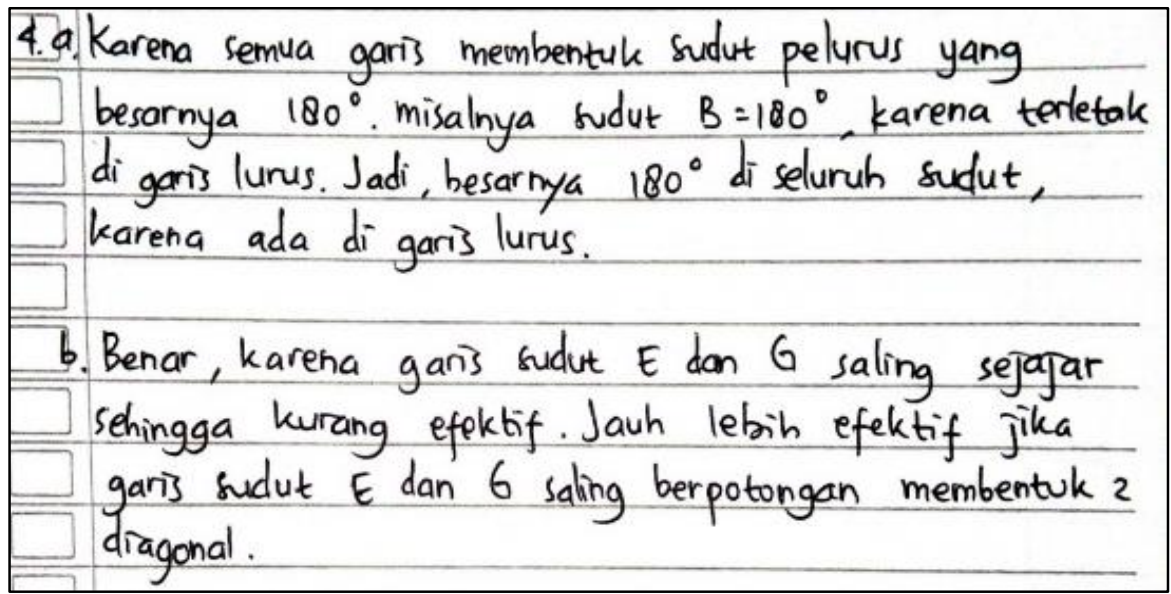

Gambar 6. Hasil Kerja Subjek AST dalam Menyelesaikan Masalah 4

Berdasarkan hasil wawancara, diperoleh informasi bahwa dalam menyelesaikan masalah 4 , subjek AST tidak mampu mengidentifikasi konsep matematika yang termuat dalam soal, tidak menyusun konsep matematika ke dalam bentuk model matematika, tidak mengidentifikasi langkahlangkah penyelesaian yang harus diselesaikan dalam penyelesaian masalah, hanya menduga benar atau tidaknya data yang diberikan, namun tidak memberikan alasan dari dugaan yang diberikan.

Berdasarkan hasil tes dan wawancara, dapat disimpulkan bahwa proses berpikir yang dilakukan AST dalam menyelesaikan masalah 4 yaitu meliputi proses conjecturing. Subjek tidak melakukan proses specializing, generalizing, dan convincing. Subjek hanya menduga jawaban berdasarkan gambar. Selain itu subjek belum memahami masalah yang diberikan pada soal, seperti yang terlihat pada petikan wawancara berikut.

Peneliti : Bagaimana cara kamu menentukan solusi yang ditanyakan pada soal nomor 4?

AST : Karena semua garis ada di garis lurus dan membentuk sudut pelurus, jadi besarnya sudutnya $180^{\circ}$.

Peneliti : Maksudnya bagaimana?

AST : Misalkan sudut $E$ dan sudut $F$ bu (sambil menunjukkan gambar), jumlah sudutnya $180^{\circ}$ karena membentuk sudut pelurus.

Peneliti : Terus?

AST : Karena membentuk sudut lurus, besarnya $180^{\circ}$ diseluruh sudut lurus.

Peneliti : Coba perhatikan kembali, apa yang diketahui dan ditanyakan dari soal?

AST : Besar sudut $A=60^{\circ}$, ditanyakan besar sudut B, $C, D, E, F, G$.

Peneliti : Coba perhatikan! (Sambil menunjukkan gambar)

Sudut A berkaitan dengan sudut yang mana?

AST : (mencoba berpikir)

Saya tidak paham bu. Menurut saya semua gambar sudut tersebut membentuk garis lurus, sehingga jumlah sudutnya $180^{\circ}$

Berdasarkan hasil analisis data subjek AST dalam penyelesaian masalah matematika, tampak bahwa AST melakukan empat proses dasar dalam berpikir. AST melakukan proses specializing dan generalizing dengan cermat dan sistematis. Selain itu, AST juga melakukan proses conjecturing dan convincing dalam setiap penyelesaian masalah. Meskipun, pada proses conjecturing, langkah penyelesaian yang digunakan masih belum beragam dan proses convincing yang dilakukan masih jarang didasarkan pada konsep-konsep matematika yang telah dipelajari.

\section{Proses Berpikir Kritis Siswa Berkemampuan Sedang}

Berikut disajikan proses berpikir kritis matematis untuk siswa dengan kemampuan sedang (siswa FDS) dalam menyelesaikan masalah berpikir kritis.

\section{Proses Berpikir Subjek FDS dalam Menyelesaikan TBKM 1}

Gambar 7 menyajikan hasil pekerjaan subjek FDS dalam menyelesaikan masalah 1. Hasil kerja subjek subjek tersebut menunjukkan bahwa subjek telah mengidentifikasi konsep yang termuat dalam argumen/pernyataan, namun masih terdapat kesalahan. 


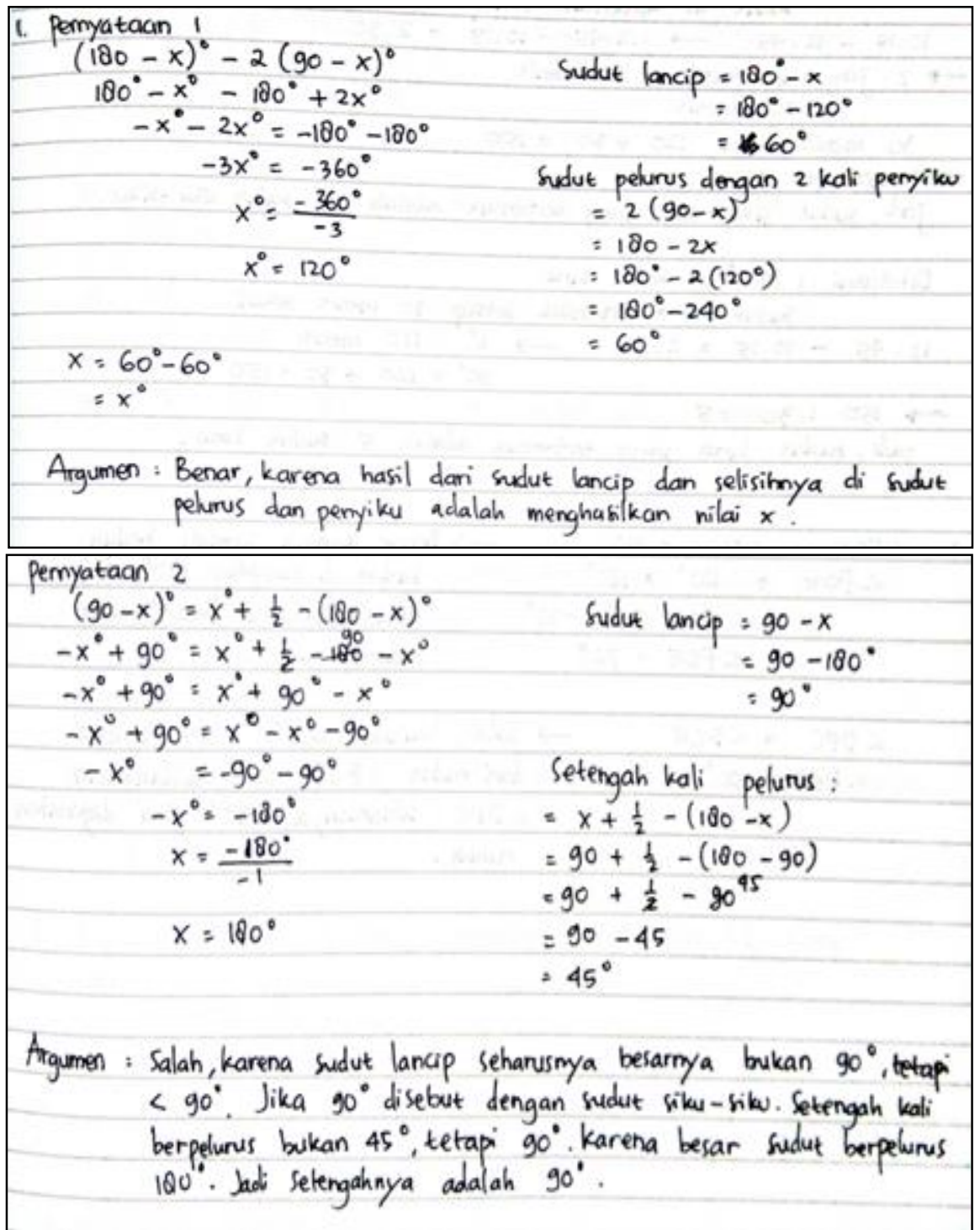

Gambar 7. Hasil Kerja Subjek FDS dalam Menyelesaikan Masalah 1

Subjek menguraikan bentuk aljabar dengan mencari nilai $x$, kemudian mensubstitusi nilai $x$ yang diperoleh untuk mendapatkan besar sudut lancip. Subjek menentukan kebenaran serta letak kesalahan argumen/pernyataan, namun masih terdapat kesalahan pada langkah penyelesaian dan alasan yang dikemukakan. Berdasarkan hasil wawancara, diperoleh informasi bahwa dalam menyelesaikan masalah 1, subjek FDS keliru dalam mengidentifikasi konsep yang termuat dalam argumen. Meskipun subjek telah menuliskan proses perhitungan, namun masih terdapat kesalahan dalam langkah penyelesaian yang digunakan, keliru mengaitkan konsep dengan bentuk aljabar yang diberikan, keliru ketika menentukan kebenaran ataupun kesalahan suatu argumen, serta alasan yang digunakan masih kurang sesuai dengan konsep yang ditanyakan.

Berdasarkan hasil tes dan wawancara tersebut, dapat disimpulkan bahwa proses berpikir yang dilakukan FDS dalam menyelesaikan masalah 1 yaitu meliputi proses specializing, generalizing, dan conjecturing. Proses specializing ditandai dengan keberhasilan subjek mengidentifikasi konsep yang termuat dalam argumen, meskipun masih terdapat kesalahan. Pada proses generalizing, FDS juga masih melakukan kesalahan dalam menguraikan bentuk aljabar untuk menyelesaikan masalah. Pada proses conjecturing, FDS menetapkan nilai kebenaran dari argumen yang diberikan, namun FDS keliru dalam menentukan nilai kebenaran argumen dan menentukan alasan dari kebenaran argumen.

Proses Berpikir Subjek FDS dalam Menyelesaikan TBKM 2

Gambar 8 menyajikan hasil pekerjaan subjek FDS dalam menyelesaikan masalah 2. Hasil kerja subjek FDS dalam menyelesaikan masalah 2 tersebut menunjukkan bahwa subjek telah mengidentifikasi 
masalah yang ditanyakan dengan benar, serta menyusun jawaban untuk penyelesaiaan masalah dengan benar. Hal ini menunjukkan subjek melakukan proses specializing, generalizing, conjecturing, dan convincing dengan baik ketika menyelesaikan masalah. Berdasarkan hasil wawancara, diperoleh informasi bahwa dalam menyelesaikan masalah 2, subjek FDS terlebih dahulu mengidentifikasi data yang diketahui dari masalah yang ditanyakan, merumuskan pertanyaan untuk menyelesaikan masalah dengan tepat dan benar, menyusun jawaban dari permasalahan dengan tepat dan benar. Berdasarkan hasil tes dan wawancara, dapat disimpulkan bahwa proses berpikir yang dilakukan FDS dalam menyelesaikan masalah 2 meliputi proses specializing, generalizing, conjecturing, dan convincing.

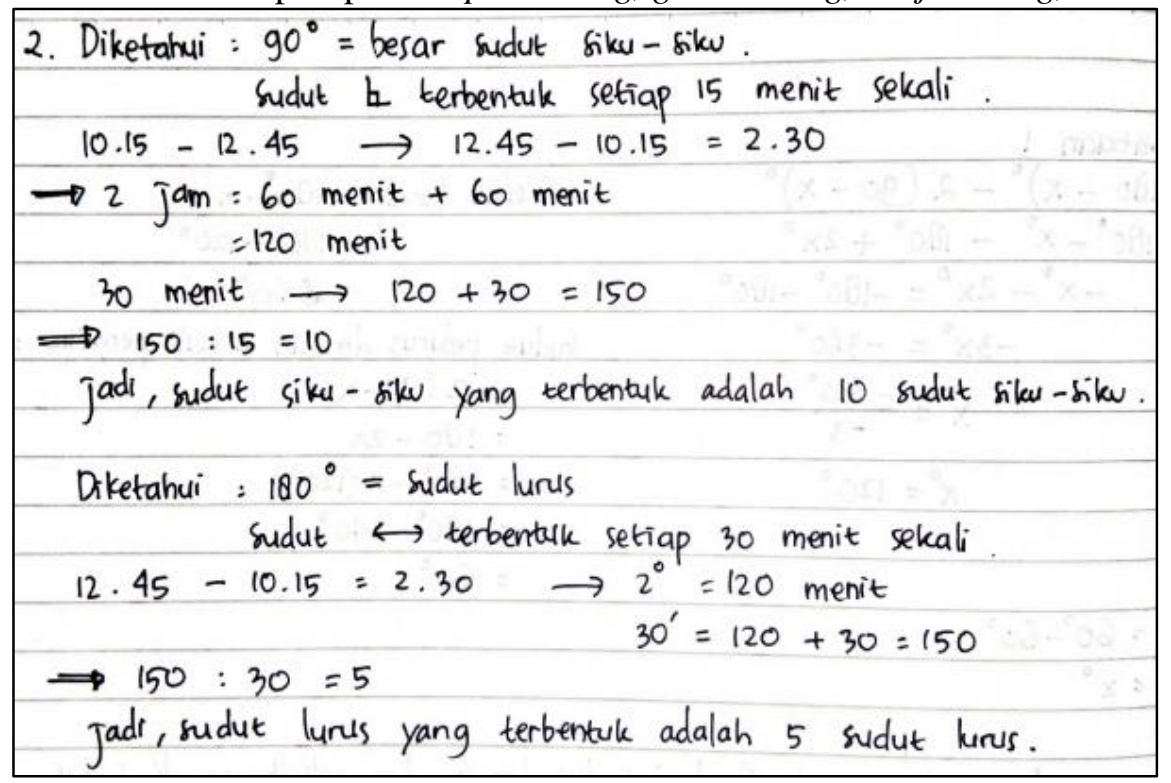

Gambar 8. Hasil Kerja Subjek FDS dalam Menyelesaikan Masalah 2

\section{Proses Berpikir Subjek FDS dalam Menyelesaikan TBKM 3}

Gambar 9 menyajikan hasil pekerjaan subjek FDS dalam menyelesaikan masalah 3. Gambar 9 menunjukkan bahwa subjek belum mengidentifikasi data dan masalah yang ditanyakan. Subjek telah menuliskan kesimpulan dengan benar, namun tidak menuliskan langkah penyelesaian. Subjek hanya menuliskan alasan dari penarikan kesimpulan. Hal ini menunjukkan bahwa siswa melakukan proses convincing dalam penyelesaian masalah. Berdasarkan hasil wawancara, diperoleh informasi bahwa subjek FDS sebenarnya memahami masalah yang ditanyakan, namun subjek tidak menuliskan syarat yang diperlukan untuk menyelesaikan masalah tersebut dan tidak menggunakan sifat-sifat sudut yang telah dipelajari. Untuk membuktikan kebenaran asumsi, subjek juga tidak menggunakan proses perhitungan matematika, tetapi hanya dengan melihat gambar. Subjek juga telah menuliskan kesimpulan dengan benar, meskipun alasan yang dikemukakan masih berdasarkan gambar.

\begin{tabular}{rl|} 
3. $\angle F O E+\angle E O C=180^{\circ}$ & $\rightarrow$ Benar, karena jumlah kedua \\
$\angle F O E+110^{\circ}=180^{\circ}$ & sudut di samping $180^{\circ}$ dan \\
$\angle F O E=180^{\circ}-110^{\circ}$ & telah diketahui besar sudut \\
$\angle F O E=70^{\circ}$ & kedvanya. \\
$\angle D F O=\angle B C E$ & $\rightarrow$ salah, karena $\angle D F 0^{\circ}$. lesih tumpul \\
$\angle D F O=10^{\circ}$ & dari sudut $\angle B C E=100^{\circ}$, Sedangkan \\
& $\angle D F O$ seharusnya $140^{\circ}$ jika digunakan \\
& numus.
\end{tabular}

Gambar 9. Hasil Kerja Subjek FDS dalam Menyelesaikan Masalah 3 


\section{Proses Berpikir Subjek FDS dalam Menyelesaikan TBKM 4}

Gambar 10 menyajikan hasil pekerjaam subjek FDS dalam menyelesaikan masalah 4. Hasil kerja subjek FDS tersebut menunjukkan bahwa subjek telah melakukan identifikasi masalah dengan benar, menyusun masalah dalam bentuk model matematika yang disertai alasan dengan benar, dan menuliskan langkah penyelesaian masalah dengan benar. Subjek belum menuliskan kesimpulan dari penyelesaian masalah dan subjek tidak menuliskan alasan ketika mengidentifikasi data relevan/tidak relevan dalam penyelesaian masalah.

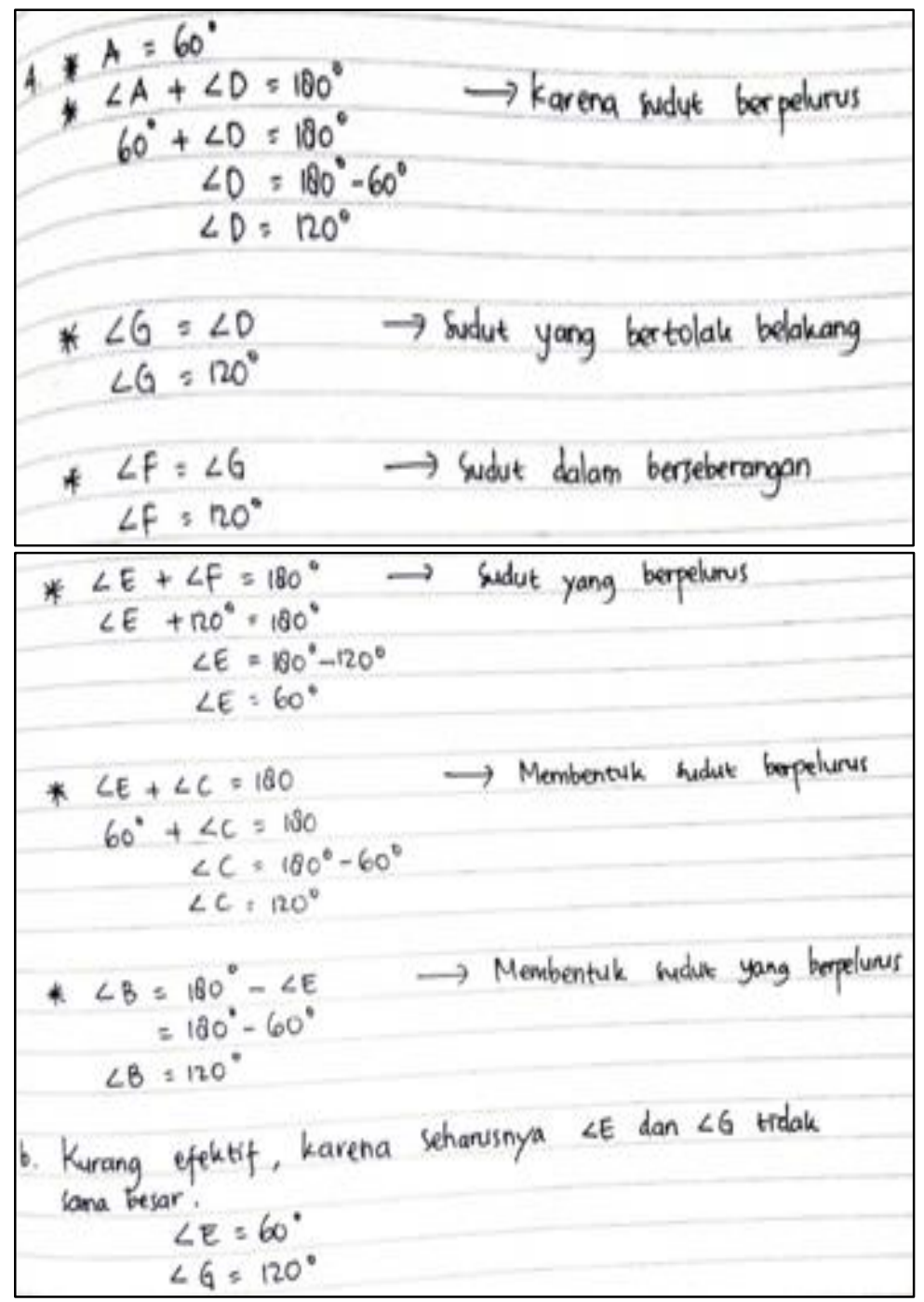

Gambar 10 Hasil Kerja Subjek FDS dalam Menyelesaikan Masalah 4

Berdasarkan hasil tes dan wawancara, dapat disimpulkan bahwa proses berpikir yang dilakukan FDS dalam menyelesaikan masalah 4 meliputi proses specializing, generalizing, conjecturing dan convincing. Pada proses specializing, FDS melakukan identifikasi terhadap informasi yang diberikan pada soal dengan baik. Pada proses generalizing, FDS telah menentukan langkah-langkah penyelesaian masalah dan menyelesaikan masalah yang diberikan dengan tepat dan benar. Pada proses conjecturing, FDS telah menjelaskan langkah penyelesaian yang digunakan dengan baik, serta memberikan alasan dari jawaban penyelesaian masalah dengan baik. Pada proses convincing, FDS mampu menjelaskan kesimpulan dengan baik, namun FDS tidak menuliskan alasan yang digunakan untuk menentukan kesimpulan pada jawaban tes.

\section{Proses Berpikir Kritis Siswa Berkemampuan Rendah}

Berikut disajikan proses berpikir kritis matematis untuk siswa dengan kemampuan rendah (siswa RFR) dalam menyelesaikan masalah berpikir kritis. 


\section{Proses Berpikir Subjek RFR dalam Menyelesaikan TBKM 1}

Gambar 11 menyajikan hasil pekerjaan subjek RFR dalam menyelesaikan masalah 1. Hasil kerja subjek RFR dalam menyelesaikan masalah 1 menunjukkan bahwa subjek belum mengidentifikasi konsep yang termuat dalam argumen/pernyataan. Terdapat kesalahan pada langkah penyelesaian yang dilakukan, subjek tidak menuliskan alasan dari langkah penyelesaian yang dilakukan, dan terdapat kesalahan pada penarikan kesimpulan dan alasan yang digunakan.

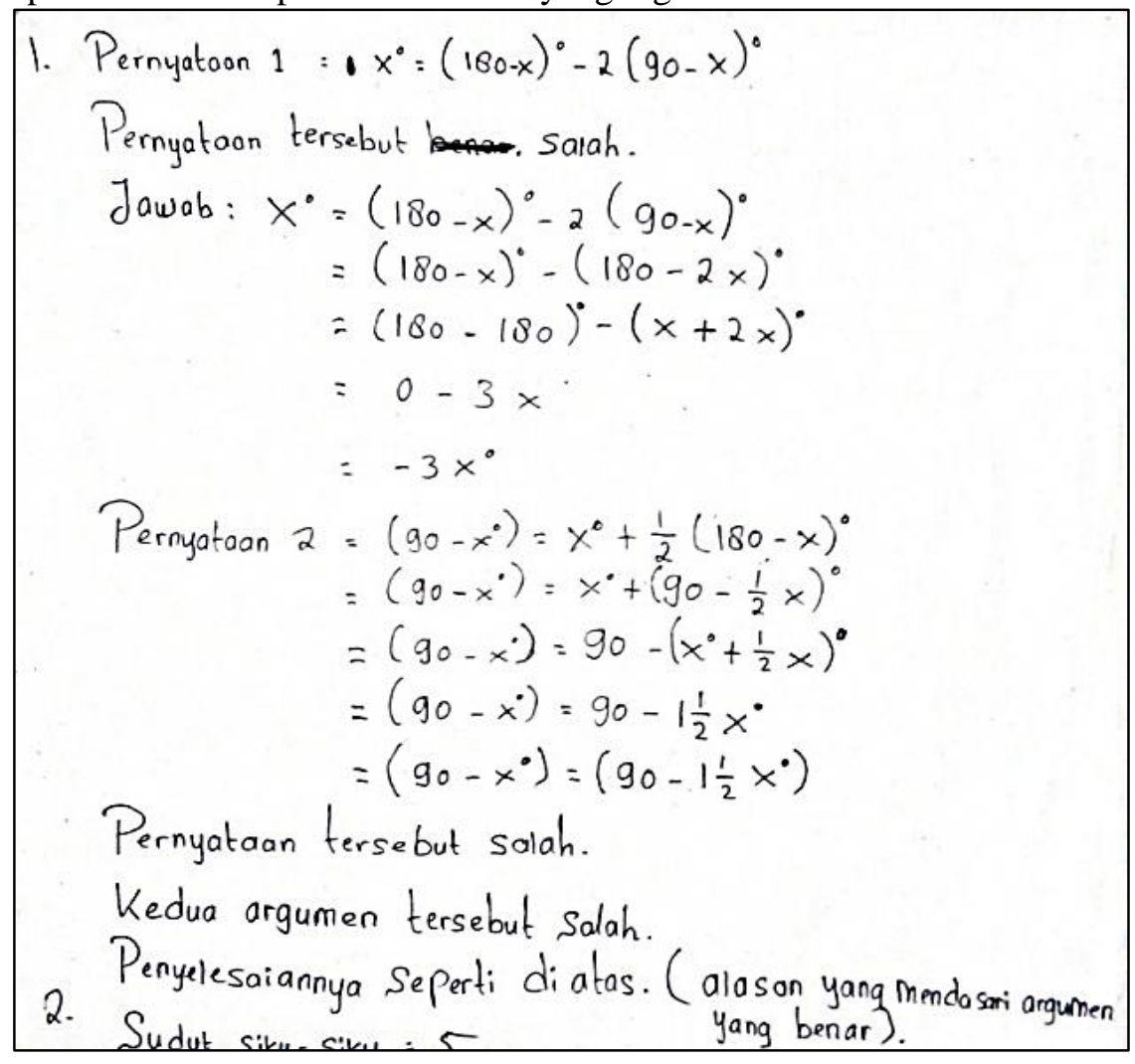

Gambar 11. Hasil kerja subjek RFR dalam menyelesaikan masalah 1

Hasil wawancara juga menunjukkan dalam menyelesaikan masalah 1 subjek RFR belum mampu mengidentifikasi konsep, terdapat kesalahan dalam menguraikan bentuk aljabar sehingga mendapatkan hasil yang keliru, serta belum mampu mengidentifikasi letak kesalahan argumen.

Berdasarkan hasil tes dan wawancara tersebut, dapat disimpulkan bahwa proses berpikir yang dilakukan RFR dalam menyelesaikan masalah 1 meliputi proses generalizing dan conjecturing. Subjek tidak melakukan proses specializing terlebih dahulu dalam menyelesaikan masalah. Subjek hanya menguraikan bentuk matematika yang diberikan pada soal. Pada proses generalizing, RFR juga masih melakukan kesalahan dalam menguraikan bentuk aljabar untuk menyelesaikan masalah. Pada proses conjecturing, RFR telah menetapkan nilai kebenaran dari argumen yang diberikan, namun RFR masih keliru dalam menentukan nilai kebenaran argumen dan menentukan alasan dari kebenaran argumen.

Proses Berpikir Subjek RFR dalam Menyelesaikan TBKM 2

Hasil pekerjaan subjek RFR dalam menyelesaikan masalah 2 disajikan pada Gambar 12. Hasil kerja subjek RFR tersebut menunjukkan bahwa subjek tidak mengidentifikasi fakta dan masalah yang ditanyakan pada soal. Subjek juga keliru dalam memahami soal. Hal tersebut terkonfirmasi dari hasil wawancara, dimana siswa mengaku merasa kesulitan untuk memahami masalah, sehingga jawaban yang diperoleh hanya menebak-nebak saja. 


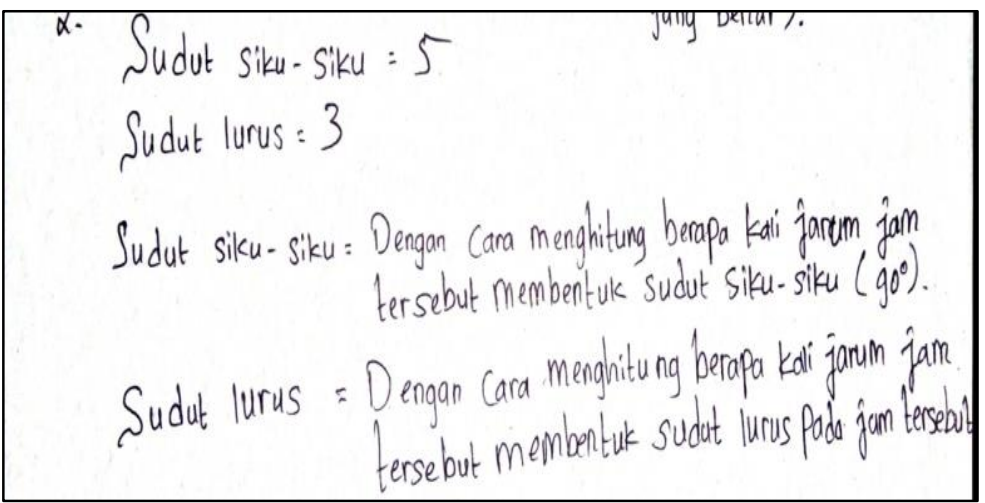

Gambar 12. Hasil Kerja Subjek RFR dalam Menyelesaikan Masalah 2

Berdasarkan hasil tes dan wawancara, dapat disimpulkan bahwa proses berpikir yang dilakukan RFR dalam menyelesaikan masalah 2 meliputi proses specializing, generalizing, dan conjecturing. Pada proses specializing, RFR telah mengidentifikasi informasi yang diketahui dan ditanyakan dari soal. Pada proses generalizing, RFR menjelaskan langkah-langkah penyelesaian yang harus dilakukan, namun langkah penyelesaian yang dilakukan salah. Pada proses conjecturing, RFR hanya menduga jawaban, namun tidak didasarkan pada konsep matematika.

\section{Proses Berpikir Subjek RFR dalam Menyelesaikan TBKM 3}

Hasil pekerjaan subjek RFR dalam menyelesaikan masalah 3 disajikan pada Gambar 13. Hasil kerja subjek RFR pada Gambar 13 menunjukkan bahwa subjek tidak memahami masalah yang disajikan dalam soal, sehingga kesulitan dalam menentukan langkah-langkah penyelesaian yang harus digunakan. Berdasarkan hasil wawancara, diperoleh informasi bahwa dalam menyelesaikan masalah 3, subjek RFR tidak memahami masalah yang ditanyakan, hanya menggunakan busur derajat dalam menyelesaikan masalah.

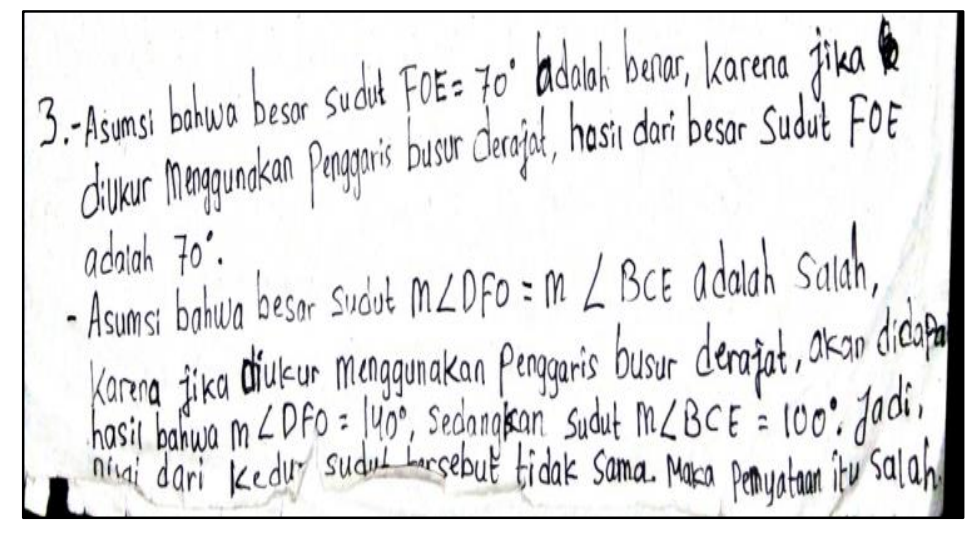

Gambar 13. Hasil Kerja Subjek RFR dalam Menyelesaikan Masalah 3

Berdasarkan hasil tes dan wawancara, dapat disimpulkan bahwa proses berpikir yang dilakukan RFR dalam menyelesaikan masalah 3 hanya meliputi proses conjecturing. Subjek hanya menduga jawaban dan menyelesaikan masalah dengan menggunakan busur derajat dan tidak mengaitkan dengan konsep matematika. Selain itu, RFR juga tidak memahami langkah penyelesaian yang harus digunakan dalam penyelesaian masalah.

\section{Proses Berpikir Subjek RFR dalam Menyelesaikan TBKM 4}

Hasil pekerjaan subjek RFR dalam menyelesaikan masalah 4 seperti ditunjukkan pada Gambar 14. Hasil kerja subjek RFR dalam menyelesaikan masalah 4 menunjukkan bahwa subjek tidak melakukan identifikasi terhadap apa saja yang ditanyakan pada soal dan masih terdapat kesalahan dalam menentukan penyelesaian masalah. 


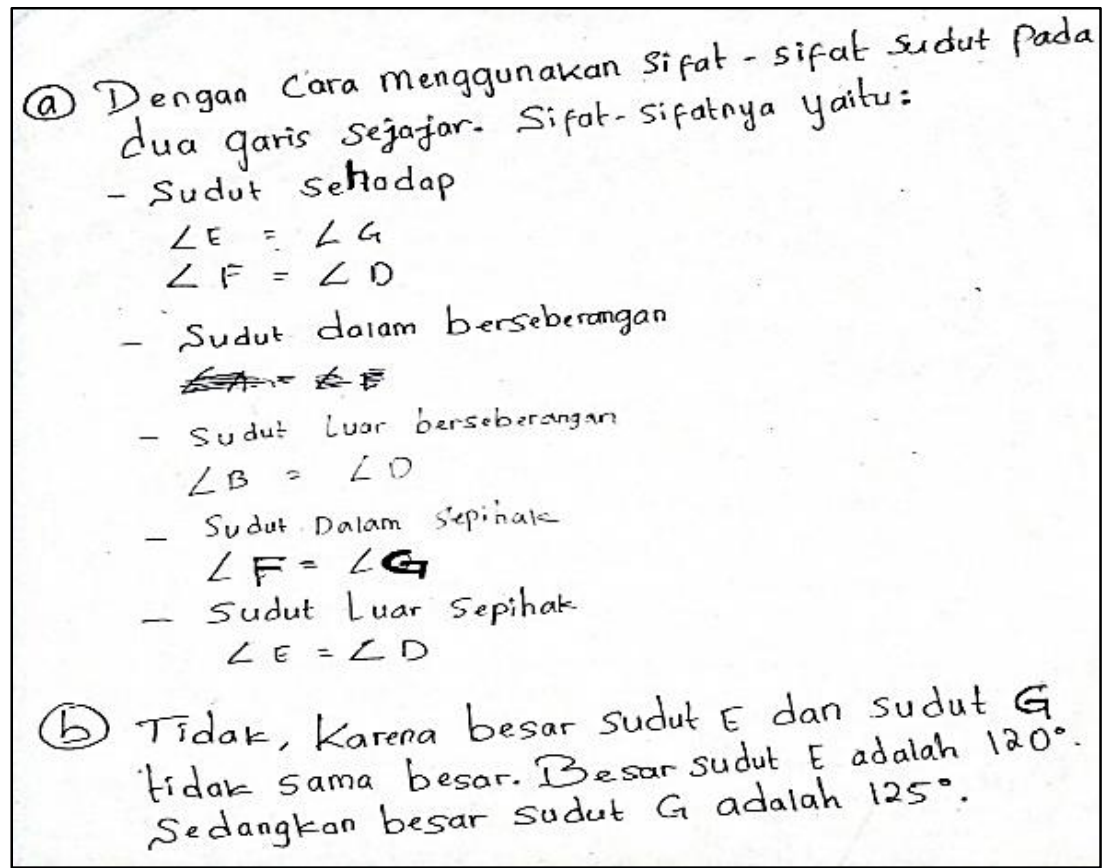

Gambar 14. Hasil Kerja Subjek RFR dalam Menyelesaikan Masalah 4

Dari hasil wawancara subjek RFR menyatakan telah mengidentifikasi konsep, namun tidak memahami masalah yang ditanyakan, serta masih keliru dalam menentukan sudut yang terbentuk pada dua garis sejajar. Berdasarkan hasil tes dan wawancara, dapat disimpulkan bahwa proses berpikir yang dilakukan RFR dalam menyelesaikan masalah 4 hanya pada proses conjecturing. RFR hanya menduga jawaban berdasarkan informasi yang diberikan, tanpa menggunakan langkah-langkah penyelesaian yang diperlukan dalam penyelesaian masalah.

\section{Pembahasan}

Pada saat menyelesaikan masalah, siswa berkemampuan tinggi membaca dan menganalisis masalah secara seksama, sehingga diperoleh informasi-informasi atau fakta-fakta yang diketahui dan informasi-informasi yang diperlukan untuk menyelesaikan masalah. Pada proses specializing, siswa berkemampuan tinggi membaca informasi dengan cermat dan teliti serta mengidentifikasi informasi yang diperlukan untuk menyelesaikan masalah yang diberikan. Pada proses generalizing, siswa berkemampuan tinggi menuliskan langkah-langkah penyelesaian serta menguraikan proses perhitungan matematika dari bentuk aljabar yang disajikan pada soal untuk memperoleh penyelesaian yang sesuai dengan maksud soal secara rinci dan cermat. Pada proses conjecturing, siswa memilih berbagai penyelesaian masalah dan mencoba untuk menyelesaikannya untuk mendapatkan kesimpulan yang tepat dari penyelesaian masalah. Pada proses convincing, siswa menjelaskan alasan yang digunakan dalam penyelesaian masalah secara logis dan didasarkan pada konsep matematika, namun siswa masih kurang percaya diri dalam menjelaskan langkah penyelesaian masalah yng dilakukan untuk menyelesaikan masalah yang diberikan. Hal ini sesuai dengan pendapat yang dikemukakan Wardhani et al. (2016) yang menyatakan bahwa pada hakikatnya, siswa berkemampuan tinggi mampu menyelesaikan masalah yang diberikan dengan baik sehingga memperoleh solusi yang tepat.

Siswa berkemampuan sedang dan rendah terlihat kurang memahami maksud dari masalah yang diberikan. Siswa berkemampuan rendah menjelaskan informasi yang terdapat pada masalah secara berbelit-belit dan informasi yang diberikan masih kurang tepat. Siswa belum mampu menjelaskan informasi penting apa saja yang diberikan pada soal. Pada saat diminta menjelaskan langkah penyelesaian, siswa memberikan penjelasan yang berbelit-belit terhadap penyelesaian masalah yang dibuat. Meskipun peneliti memberikan pertanyaan yang mengarah pada solusi yang tepat, siswa masih belum mampu memahami letak kesalahan pada solusi yang telah dibuat. Hal ini sesuai dengan pendapat Yeo (2009) yang menyatakan bahwa siswa yang memiliki pengetahuan dan strategi yang kurang cenderung tidak mampu menggunakan matematika dengan benar untuk menyelesaikan masalah matematika. Pada saat ditanyakan mengenai proses penyelesaian masalah, siswa belum mampu 
menjelaskan dengan baik, bahkan menjelaskan secara berbelit-belit langkah penyelesaian yang telah dibuat. Siswa menuliskan informasi yang diberikan meskipun informasi yang dipahami kurang tepat. Ketika diminta untuk menjelaskan langkah penyelesaian masalah, siswa berusaha mencari-cari alasan penyelesaian lain serta memberikan penjelasan yang sulit dipahami. Temuan ini sejalan dengan pendapat pendapat de Villiers dan Jugmohan (2012) yang menyebutkan bahwa siswa yang hanya mengingat dan menggunakan prosedur atau aturan yang ada akan kesulitan untuk memberikan penjelasan terhadap apa yang telah dikerjakan.

Temuan penelitian ini menunjukkan bahwa kemampuan berpikir kritis matematis siswa dalam pembelajaran matematika melalui penerapan discovery learning belum optimal, terutama bagi siswa yang memiliki kemampuan akademik sedang dan rendah. Untuk itu diperlukan pembiasaan kepada siswa untuk melatihkan kemampuan berpikir tingkat tingginya melalui berbagai model pembelajaran konstruktivisme. Beberapa model pembelajaran yang dapat digunakan untuk melatihkan kemampuan berpikir tingkat tinggi, termasuk berpikir kritis seperti Creative Problem Solving (Apino \& Retnawati, 2017; Apino \& Retnawati, 2019) dan Problem-Based Learning (Jailani, Sugiman \& Apino, 2017; Djidu \& Jailani, 2018). Disamping itu, siswa juga perlu dibiasakan untuk mengerjakan soal-soal yang mengukur kemampuan berpikir tingkat tinggi serta soal-soal penyelesaian masalah yang setara dengan soal-soal TIMSS dan PISA (Retnawati, Djidu, Kartianom, Apino, \& Anazifa, 2018).

\section{SIMPULAN}

Hasil penelitian menunjukkan bahwa tidak semua tahapan proses berpikir kritis muncul secara bersamaan dalam penyelesaian masalah yang dilakukan siswa untuk setiap indikator berpikir kritis. Pada alur penyelesaian masalah, tampak bahwa siswa berkemampuan tinggi melakukan empat proses dasar dalam berpikir. Siswa berkemampuan tinggi mampu melakukan proses specializing dan generalizing dengan cermat dan sistematis. Selain itu, siswa berkemampuan tinggi juga mampu melakukan proses conjecturing dan convincing dalam setiap penyelesaian masalah, meskipun pada proses conjecturing, langkah penyelesaian yang digunakan masih belum beragam. Selanjutnya, siswa berkemampuan sedang telah mampu melakukan proses specializing secara terurut dan terperinci pada alur penyelesaian masalah, namun pada proses generalizing, siswa belum memperluas cakupan hasil penyelesaian yang diperoleh. Selain itu, pada proses conjecturing dan convincing, siswa dengan kemampuan sedang perlu dilatih dalam menganalogikan masalah yang diselesaikan dengan kasus yang sejenis, serta dilatih untuk memberikan alasan dari langkah penyelesaian masalah yang digunakan. Untuk siswa berkemampuan rendah, siswa belum mampu melakukan proses specializing, selain itu, siswa juga belum mampu memahami masalah serta tidak berusaha menyusun dan mencoba berbagai strategi yang mungkin untuk menyelesaikan masalah. Dengan demikian melalui penerapan discovery learning dalam pembelajaran matematika belum mampu mengembangkan proses berpikir kritis siswa secara optimal.

Berdasarkan hasil penelitian yang telah dikemukakan, ada beberapa saran yang dilakukan, diantarnya guru harus membiasakan pembelajaran berkelompok, agar siswa menjadi lebih aktif dalam proses pembelajaran, sehingga siswa terbiasa dalam berdiskusi dan bisa merangsang pola pikir siswa untuk mencari dan menyelesaikan masalah tanpa bantuan orang lain. Selain itu, pembelajaran matematika juga harus membiasakan siswa untuk menyelesaikan soal-soal yang membutuhkan kemampuan berpikir tingkat tinggi. Penelitian ini juga dapat dijadikan acuan bagi peneliti lainnya dalam hal untuk melakukan penelitian terkait peningkatan kemampuan berpikir kritis siswa. Kekurangan dalam penelitian ini hendaknya dapat dijadikan sebagai bahan masukan dan pertimbangan untuk penilaian serupa di masa yang akan datang.

\section{DAFTAR PUSTAKA}

Amir, M. F. (2015). Proses berpikir kritis siswa sekolah dasar dalam memecahkan masalah berbentuk soal cerita matematika berdasarkan gaya belajar. Jurnal Math Educator Nusantara: Wahana Publikasi Karya Tulis Ilmiah Di Bidang Pendidikan Matematika, 1(2), 159-170. Retrieved from http://ojs.unpkediri.ac.id/index.php/matematika/article/view/235

Apino, E., \& Retnawati, H. (2017). Developing instructional design to improve mathematical higher order thinking skills of students. Journal of Physics: Conference Series, 812, 1-7. doi: http://doi.org/10.1088/1742-6596/812/1/012100

Apino, E., \& Retnawati, H. (2019). Creative problem solving for improving students' higher order 
thinking skills (HOTS) and characters. In E. Retnawati, A. Ghufron, M. Marzuki, A. C. Pierawan, \& A. Ashadi (Eds.), Character Education for 21st Century Global Citizens: Proceedings of The 2nd International Conference on Teacher Education and Professional Development (pp. 249256). London, UK: Taylor \& Francais Group.

Danaryanti, A., \& Lestari, A. T. (2018). Analisis kemampuan berpikir kritis dalam matematika mengacu pada watson-glaser critical thinking appraisal pada siswa kelas VIII SMP negeri di banjarmasin tengah tahun pelajaran 2016/2017. EDU-MAT: Jurnal Pendidikan Matematika, 5(2), 116-126. doi:http://dx.doi.org/10.20527/edumat.v5i2.4631

de Villiers, M., \& Jugmohan, J. (2012). Learners' conceptualisation of the sine function during an introductory activity using sketchpad at grade 10 level. Educação Matemática Pesquisa: Revista Do Programa de Estudos Pós-Graduados Em Educação Matemática, 14(1), 9-30. Retrieved from https://revistas.pucsp.br/index.php/emp/article/viewFile/8750/6826

Djidu, H., \& Jailani, J. (2018). Developing problem based calculus learning model. Jurnal Kependidikan: Penelitian Inovasi Pembelajaran, 2(1), 68-84. doi:https://doi.org/10.21831/jk.v2i1.12689

Ennis, R. H. (1989). Critical thinking and subject specificity: Clarification and needed research. Educational Researcher, 18(3), 4-10. doi:https://doi.org/10.3102/0013189X018003004

Faridah, S. (2013). Proses berpikir siswa dalam pemecahan masalah pada materi barisan dan deret. Universtas Negeri Malang.

Hendriana, H., \& Soemarmo, U. (2017). Penilaian pembelajaran matematika. Bandung: PT Refika Aditama.

Hosnan, M. (2014). Pendekatan saintifik dan konstekstual dalam pembelajaran abad 21. Bogor: Ghalia Indonesia.

Irawan, T. A., Rahardjo, S. B., \& Sarwanto, S. (2017). Analisis kemampuan berpikir kritis kelas VII-A SMP Negeri 1 Jaten. Prosiding Seminar Nasional Pendidikan Sains (SNPS) (pp. 232-236). Surakarta: FKIP Universitas Sebelas Maret.

Jailani, J., Sugiman, S., \& Apino, E. (2017). Implementing the problem-based learning in order to improve the students' HOTS and characters. Jurnal Riset Pendidikan Matematika, 4(2), 247-259. doi: https://doi.org/10.21831/jrpm.v4i2.17674

Jumaisyaroh, T., Napitupulu, E., \& Hasratuddin, H. (2015). Peningkatan kemampuan berpikir kritis matematis dan kemandirian belajar siswa SMP melalui pembelajaran berbasis masalah. Kreano, $\begin{array}{llll}\text { Jurnal Matematika } & \text { Kreatif-Inovatif, } & \text { 5(2), }\end{array}$ doi:https://doi.org/10.15294/kreano.v5i2.3325

Lin, F.-L. (2006). Designing mathematics conjecturing activities to foster thinking and constructing actively. Keynote address in the APEC-TSUKUBA International Conference, Japan.

Maričić, S., \& Špijunović, K. (2015). Developing critical thinking in elementary mathematics education through a suitable selection of content and overall student performance. Procedia-Social and Behavioral Sciences, 180, 653-659. doi:https://doi.org/10.1016/j.sbspro.2015.02.174

Mason, J., Burton, L., \& Stacey, K. (2010). Thinking mathematically. London, UK. Pearson Education.

Maulana, M. (2017). Konsep dasar matematika dan pengembangan kemampuan berpikir kritis-kreatif. Sumedang: UPI Sumedang Press.

Miles, M. B., \& Huberman, A. M. (1992). Analisis data kualitatif (T. R. Rosidi, trans.). Jakarta: Universitas Indonesia. Original work published in 1984.

NCTM. (2000). Principles and standards for school mathematics. Reston, VA: Author.

Polya, G. (1973). How to solve it second edition (2nd ed.). New York, NY: Princeton University Press.

Razak, F. (2017). Hubungan kemampuan awal terhadap kemampuan berpikir kritis matematika pada siswa kelas VII SMP pesantren immim putri minasatene. Mosharafa: Jurnal Pendidikan Matematika, 6(1), 117-128. doi:https://doi.org/10.31980/mosharafa.v8i1.406

Retnawati, H., Djidu, H., Kartianom, K., Apino, E., \& Anazifa, R. D. (2018). Teachers' knowledge about higher-order thinking skills and its learning strategy. Problems of Education in the 21 st Century, 
76(2), 215-230. Retrieved from http://www.scientiasocialis.lt/pec/node/1121

Richard, P., \& Elder, L. (2005). Critical thinking competency standars. Tomales, CA: Foundation for Critical Thinking Press.

Rohaeti, E. E. (2010). Critical and creative mathematical thinking of junior high school student. Educationist: Jurnal Kajian Filosofi, Teori, Kualitas, dan Manajemen Pendidikan, 4(2), 99-106. Retrieved from http://jurnal.upi.edu/educationist/view/74/critical-and-creative-mathematicalthinking-ofjunior-high-school-students.html

Ruseffendi, E. (2006). Pengantar kepada guru mengembangkan kompetensinya dalam pengajaran matematika untuk meningkatkan CBSA. Bandung: Tarsito.

Sani, R. A. (2015). Pembelajaran saintifik untuk implementasi Kurikulum 2013. Jakarta: Bumi Aksara.

Setyaningsih, T. D., \& Agoestanto, A. (2014). Identifikasi tahap berpikir kritis siswa menggunakan PBL dalam tugas pengajuan masalah matematika. Kreano, Jurnal Matematika Kreatif-Inovatif, 5(2), 180-187. doi:https://doi.org/10.15294/kreano.v5i2.4544

Subanji, S. (2006). Berpikir pseudo penalaran kovariasi dalam mengkonstruksi grafik fungsi kejadian dinamik: Sebuah analisis berdasarkan kerangka kerja VL2P dan implikasinya pada pembelajaran matematika. Jurnal Ilmu Pendidikan, 13(1), 1-8. doi:http://dx.doi.org/10.17977/jip.v13i1.57

Sumardyono, S., Priatna, N., \& Anggraena, Y. (2016). Guru pembelajar modul matematika SMP: Kelompok kompetensi C pedagogik model pembelajaran matematika. Jakarta: Direktorat Jenderal Guru dan Tenaga Kependidikan.

Suriawati, S., \& Mundilarto, M. (2019). SETS approach-based audiovisual media for improving the students' critical thinking skills. Psychology, Evaluation, and Technology in Educational Research, 1(2), 95-103. doi:http://dx.doi.org/10.33292/petier.v1i2.15

Wardhani, W. A., Subanji, S., \& Dwiyana, D. (2016). Proses berpikir siswa berdasarkan kerangka kerja mason. Jurnal Pendidikan: Teori, Penelitian, dan Pengembangan, 1(3), 297-313. doi: http://dx.doi.org/10.17977/jp.v1i3.6152

Widodo, S. A. (2012). Proses berpikir mahasiswa dalam menyelesaikan masalah matematika. Prosiding Seminar Nasional Matematika dan Pendidikan Matematika FMIPA Universitas Negeri Yogyakarta, 795-800. Retrieved from https://eprints.uny.ac.id/10097/

Yeo, K. K. J. (2009). Secondary 2 students' difficulties in solving non-routine problems. International Journal for Mathematics Teaching and Learning. 